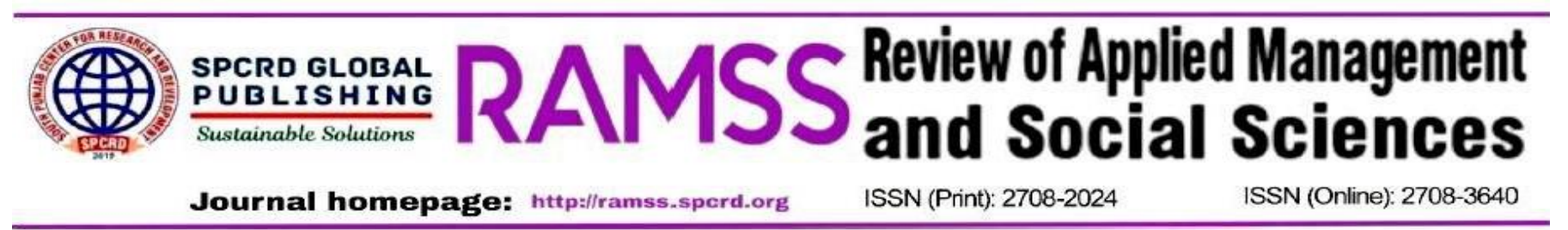

\title{
Students' Age, Perceptions of Poor Performance, and Fear of Negative Assessment in English Speaking as Predictors of Academic Performance in Male and Female Students
}

\author{
${ }^{a}$ Rafaquat Ali, ${ }^{\text {b }}$ Bushra Shoukat, ${ }^{\mathrm{c}}$ Rabia Bahoo \\ ${ }^{a}$ Assistant Professor, Department of Education, Bahawalnagar Campus, Bahawalnagar, The Islamia University \\ of Bahawalpur, Pakistan \\ Email: rafaquatiub@yahoo.com \\ ${ }^{\mathrm{b}}$ Assistant Professor, Department of English, Bahawalnagar Campus, Bahawalnagar, The Islamia University of \\ Bahawalpur, Pakistan \\ Email: bushra.shoukat@iub.edu.pk \\ ${ }^{\mathrm{c}}$ Lecturer, Department of Education, Government Sadiq College women University, Bahawalpur, Pakistan \\ Email: rabia.bahoo@gscwu.edu.pk
}

\begin{tabular}{l}
\hline ARTICLE DETAILS \\
\hline History: \\
Accepted 22 December 2021 \\
Available Online December 2021
\end{tabular}

\section{Keywords:}

English Speech Anxiety, Fear of Negative Evaluation, Perceptions of poor performance, Negative Thoughts in English Speech, Implicit Theories, Entity Theories of Intelligence and Ability

\section{JEL Classification:} P36

DOI: $10.47067 /$ ramss.v4i4.191

\begin{abstract}
The students' implicit theories of intelligence and ability play a crucial role in determining their interest and effort in their studies. The negative mindset promotes poor perceptions of performance and fear of negative evaluation in students, which negatively impacts their learning and academic performance. The English language experts have tried to understand these perceptions of poor performance and fear of negative evaluation in English speech anxiety. Gender and age differences are present in implicit theories and perceptions of poor performance, fear of negative evaluation, and speech anxiety. Therefore, the current study explored the role of age in perceptions of poor performance and fear of negative evaluation in English speaking anxiety and academic performance among male and female students. The sample of the study was 956 university students. Generalized structured component analysis multi-group approach revealed the differing impacts of age on dimensions of negative thoughts in English speaking and academic performance in male and female students. The direct effect of age on students' academic performance was insignificant. However, the students' perceptions of poor performance mediated the impact of age on academic performance. The effect of perceptions of poor performance on academic performance was negative compared to the positive effect of fear of negative evaluation on students' academic performance.
\end{abstract}

(C) 2021 The authors. Published by SPCRD Global Publishing. This is an open-access article under the Creative Commons Attribution-

NonCommercial 4.0

Corresponding author's email address: rafaquatiub@yahoo.com 


\section{Introduction}

Nowadays, academicians often use implicit theories to explain students' different beliefs, selfperceptions, learning engagements, and learning outcomes. Implicit theories, also called mindset, self-theories, lay theories, or naive theories (Lüftenegger \& Chen, 2017), assume that humans hold distinctive beliefs about human characteristics (Carr et al., 2012). The process of socialization and daily learning experiences shape students' self-perceptions and implicit theories (Carr et al., 2012). The literature in implicit theories compares humans from two perspectives; entity and incremental perspectives (Plaks, 2017). An entity perspective entails that human attributes are considered relatively fixed compared to the incremental view that human characteristics can change (Carr et al., 2012). These implicit theories provide applicable and substantial insights and understanding of human judgments and reactions (Dweck et al., 1995). Implicit theories provide a framework which can explain students' learning and learning process (Dweck, 2006).

Implicit theories of intelligence and ability provided an explicable understanding of students' effort and persistence in learning (Dweck, 2000, 2006). Positive beliefs about effort assist students to feel that they can control the learning situation (Bernstein, 2006). In this way, students' mindset beliefs or implicit theories determine their decision of effort in any educational activity and affect the learning outcomes and academic performance (Wilson, 2015). Students are always eager to learn in an incremental or growth mindset (Dweck, 2000) because they perceive intelligence as incremental and have positive beliefs of effort (Duco, 2016). They assume that humans can control and change themselves when motivated, have an opportunity, and acquire required training (Carr et al., 2012). The students' who have entity mindset and negative perceptions of their ability and intelligence always expect poor achievements and appear to have learned helplessness (Chapman, 1988; Dweck, 2006). As a result, the students with fixed mindset or entity intelligence implicitly show worse academic performance (Dweck, 2006). Most of the time, these students appear to be more concerned about their reputation (Dweck, 2000) and fail to persist if they face problems (Dweck, 2006). It is evident that if students consider their failure or success due to ability rather than effort, they can be more adversely affected by the negative evaluation (Bernstein, 2006). If the evaluation is negative, the students' may interpret negative feedback through their implicit theories. If the fixed mindset students receive negative feedback and assessment, they may interpret that they have the poor ability and can even quit to effort for learning and develop a defeatist attitude and fear to challenging situations (Bruce, 2003). In this way, the negative feedback becomes a hurdle in students' learning in general, but it depends on the students' mindset that interprets it (Fong et al., 2019). The development of the perception of poor performance is quite complex. Students' perceptions of personal abilities depend on their self-determined level of success or failure and review of previous success and failure (Bruce, 2003).

Another ramification of self-perception is academic self-perception. The students who have positive academic self-perception but have learning disabilities use strategies that can help them to overcome their disability as compared to students of learning disability who have negative academic self-perception (Meltzer et al., 2004). Likewise, someone's perceptions of self-efficacy have emotional implications. The perceived failure to function or overcome a disliking event raises fear in someone. The discrepancies between actual and self-perceived coping efficacy produce anxiety in students (Bandura, 1982). Hence, the role of students' self-perception appears critical in their learning (Bruce, 2003). The negative perceptions and evaluations create fears in students. The common fears prevalent in students are fear of failure and humiliation that negatively impact their academic achievements (Bledsoe \& Baskin, 2014). 
However, there are gender differences in receiving the negative evaluation. Teachers mostly give negative assessment feedback in terms of lack of ability to female students compared to negative feedback in terms of lack of motivation to male students (Dweck et al., 1978). Therefore, abilityoriented negative feedback to girls may have a more distressing impact on their self-esteem. The distress arising from being evaluated drives students to focus on preventing negative evaluation rather than improving the behaviour (Carleton et al., 2006). However, if students realize the importance of learning activities pivotal for learning, they can reduce their anxiety (Downing et al., 2020). The negative evaluation and poor perceptions of performance produce different fears and anxieties in students having negative mindset (Kitano, 2001). Anxiety, in general, is adverse to students' academic achievement (Seipp, 1991; Zhang \& Henderson, 2014). Therefore, negative evaluation and perceptions of poor performance are considered an essential construct in fostering anxieties in students (Cho et al., 2004). Speaking anxiety is a critical issue for language learning, especially in foreign and second languages (Pappamihiel, 2002; Thompson et al., 2013). However, the growing importance of English has acquired researchers' attention, and researchers are paying attention to English speech anxiety (Liu \& Jackson, 2008). English language speaking anxiety is a fear someone feels of speaking in situations involving English (Gardner \& MacIntyre, 1993). The research has revealed the negative association of English speaking anxiety in English medium instruction with academic performance (Aida, 1994). However, implicit theories of intelligence and abilities provided significant insight into how these anxieties function and develop in second language learners. In this way, the students who have an implicit entity mindset can assume that English speaking depends on innate ability and talent, and they presume not to have the natural talent to speak English; therefore, they develop speaking apprehension and poor self-perception of English speaking (Stewart et al., 2019).

Furthermore, cognitive models of social anxiety emphasize the importance of negative evaluation by others and the self as essential components of speaking anxiety (Clark, 2001). English speaking skills put students under strain, especially second language learners (Nunan, 2003). Therefore, it is crucial to understand the roles of fear of negative evaluation and perception of the performance of English speaking in academic performance in male and female higher education students.

\section{Conceptual Framework}

Implicit theories and mindset provide an avenue to explain students' perceptions, selfevaluation, and interpretation of others' evaluation of their English speaking and academic performance. Speech anxiety is related positively to students' fear of negative evaluation, and similarly, they have higher speech anxieties if they perceive themselves as less capable of speaking English than their peers (Kitano, 2001). Furthermore, if they have a negative mindset or entity mindset, they can have even problems with effort in learning (Bruce, 2003), and negative evaluation by others may drastically affect their desire to speak English (Fong et al., 2019). Furthermore, English speaking anxiety has a negative association with students' academic performance (Aida, 1994) self-competence (Liu \& Jackson, 2008), and a positive association with depression (D'Esposito et al., 2011). It negatively impacts students' motivation to learn in English learning environments and damages their self-worth and interpersonal relationships (D'Esposito et al., 2011; Young, 1991).

Furthermore, age may be an element that can change the students' implicit theories. The Pakistani universities opted for the English language as a medium of instruction. It is essential to understand the way fear of negative evaluation and poor perceptions of the performance of English 
speaking impact students. The factors of age and gender can contribute to differences in implicit theories and anxieties. The young students, as compared to old students, seem to have more English speaking anxiety (Aydin et al., 2017; Gaibani \& Elmenfi, 2016). The females also seem to feel more anxious while speaking English due to fear of negative evaluation and failure (Aydin et al., 2017). Therefore researchers in this study conceptualised that there will be different patterns in relationships of English speaking anxiety dimensions of fear of negative evaluation and perception of poor performance with age and academic grades in male and female sampled groups. The conceptual framework of the study is below:

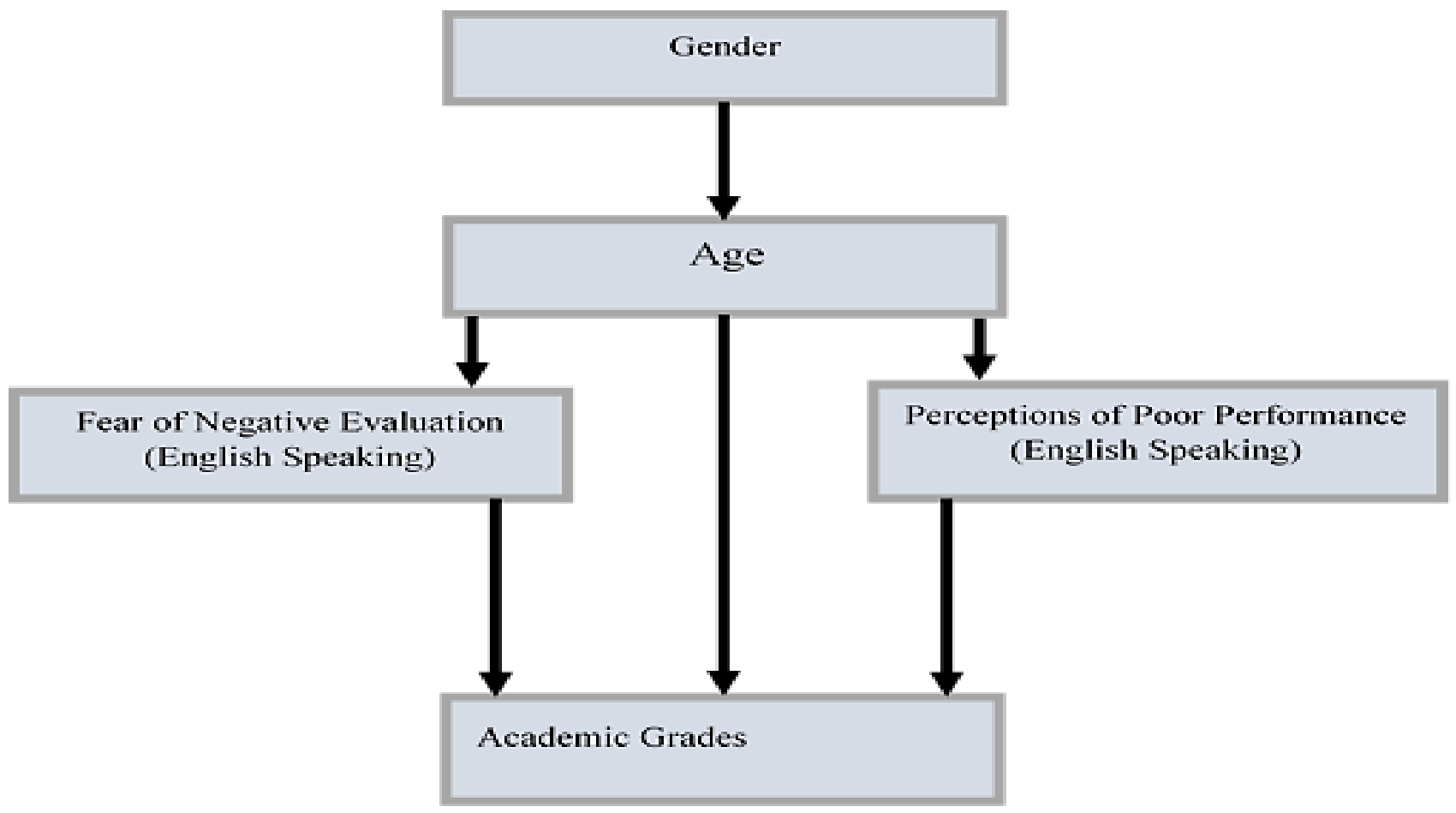

Figure 1: Conceptual Framework

\section{Objectives and Hypotheses of the study}

The current study has the following objectives:

i. To evaluate the impact of students' age on their perceptions of poor performance in English speaking in male and female students.

ii. To understand the impact of students' age on their fear of negative evaluation in speaking English in male and female students.

iii. To assess the impact of age on students' academic grades in male and female students.

iv. To identify the mediation role of students' perception of poor performance in English speaking in the impact of their age on their academic grades in male and female students.

v. To verify the mediation role of students' fear of negative evaluation in speaking English in the effect of age on their academic grades in male and female students.

Following are the postulates of this study.

i. There will be a significant impact of students' age on their perceptions of poor performance in English speaking in male and female students.

ii. There will be a significant impact of students' age on their fear of negative evaluation in speaking English in male and female students. 
iii. There will be a significant impact of age on students' academic grades in male and female students.

iv. The impact of students' age on their academic grades will be mediated by their perceptions of poor performance in English speaking in male and female students.

v. The impact of students' age on their academic grades will be mediated by their fear of negative evaluation of speaking English in male and female students.

\section{Method}

\subsection{Sample}

The sample of the study comprised 956 volunteer Pakistani university students available to participate in an online google survey from southern Punjab. The sample was split into male and female groups, and there were 410 male students and 546 female students in the sample from the English medium instructional environment. English was a foreign language for these students. Their mother-tongues were Urdu and Punjabi. However, it was observed that their routine conversation was in Urdu, which is the national language of Pakistan. It is pertinent to mention that the official language of Pakistan is English.

\subsection{Data Collection}

The Speech Anxiety Thoughts Inventory (SATI) developed by Cho et al. (2004) was considered suitable to measure students' fear of negative evaluation and perceptions of poor performance in speaking English. The SATI (Cho et al., 2004) was adopted in this study. This inventory is based on a cognitive approach, and it provides an understanding of English speaking anxiety thoughts in students of English medium instruction. The 23 statements measure two factors of speech anxiety thoughts; the fear of negative evaluation and perception of poor performance. The confirmatory factors analysis in this study affirmed the sufficient and adequate loadings of 22 items on 02 factors of perception of poor performance and fear of negative evaluation in measurement model of this study in male and female students (Figure 2 and Table No. 3). Each statement required the response of respondents on a five-point scale ranging from "I do not completely believe in the statement $=1$ " to "I completely believe on the statement $=5$ )". The students provided information about gender, age, and academic grades by selecting specified categories.

\subsection{Data Analysis}

The researchers used the Generalized Structured Component Analysis (GSCA) approach to confirm the supposed impacts of independent variables on the dependent variables in this model. The GSCA structural equation modeling does not involve the normality issues and is recommended as a more competent approach than contemporary SEM approaches in ease of usage and interpretation (Cho \& Choi, 2020). The available GSCA Pro software is used in this study to confirm the model's postulated measurement and structural indices. The sample cases were split into male and female groups to understand the impacts of gender on the model's different assumed paths and psychometric characteristics. The multi-group analysis in GSCA provided confidence intervals for path estimates in the structural model and item loadings in the measurement model across the two gender groups. The assumed model was tested for both genders to identify gender impact on the model. The inference of significance of the path estimates and loadings was based on the rule of thumb that a confidence interval calculated at $95 \%$ is significant at 0.05 level if it does not contain zero (Das, 2019). However, researchers also included p-values and confidence intervals to understand the hypotheses testing in a better way. 


\section{Results}

\subsection{Descriptive Statistics}

Table No. 1 shows mean statistics about grouping variable gender for different latent variables in the model. The mean perceptions of poor performance and fear of negative evaluation in speaking English are lower in female students than in male students. The female students are less older than the male students, and their academic grade average is higher than the male students. In this way, the grouping variable gender appears to cause or lead to differences in students' perception of poor performance, fear of negative evaluation in speaking English, students' age, and academic performance.

\begin{tabular}{|c|c|c|c|}
\hline \multicolumn{4}{|l|}{ Table No. 1} \\
\hline \multicolumn{4}{|l|}{ Descriptive Statistics } \\
\hline Variable & Gender & Mean & $\mathbf{N}$ \\
\hline \multirow{3}{*}{$\begin{array}{l}\text { Perception } \\
\text { performance }\end{array}$} & Female & 28.7 & 546 \\
\hline & Male & 31.5 & 410 \\
\hline & Total & 29.9 & 956 \\
\hline \multirow{3}{*}{ Fear of negative evaluation } & Female & 22.4 & 546 \\
\hline & Male & 23.6 & 410 \\
\hline & Total & 22.9 & 956 \\
\hline \multirow{3}{*}{ Age } & Female & 22 Yrs. & 546 \\
\hline & Male & 25 Yrs. & 410 \\
\hline & Total & 24 Yrs. & 956 \\
\hline \multirow{3}{*}{ Marks Percentage } & Female & 3.76 & 546 \\
\hline & Male & 3.49 & 410 \\
\hline & Total & 3.64 & 956 \\
\hline
\end{tabular}

\subsection{Model Fit Indices}

Different overall model fit measures in GSCA multi-group SEM approach are in Table No. 2. The FIT value of the multi-group SEM model is 0.499, which means that this model explains $44.9 \%$ variance in different indicators and components in the model (Hwang, 2009). However, the FITs value of 0.581 indicated that the structural model successfully explains $58.1 \%$ variance in different components in this model (Hwang et al., 2017). The FITm value in this model is 0.496 , which shows that the measurement model elaborates 49.6 percent variance in different indicators or items in the measurement model (Hwang et al., 2017). Overall, this model has an acceptable fit with a goodness of fit index (GFI) value of 0.993, and a standardized root mean square residual (SRMR) value of o.037 (Hwang \& Takane, 2014).

\begin{tabular}{|l|l|l|l|l|}
\hline \multicolumn{5}{|l|}{ Table No. 2} \\
\hline Model Fit Measures & FITs & FITm & GFI & SRMR \\
\hline FIT & 0.581 & 0.496 & 0.993 & 0.037 \\
\hline 0.499 &
\end{tabular}

\subsubsection{Measurement Model}

The measurement model results are in Table Nos. 3, 4, 5, 6, and Figures 2 and 3. The 13 items confirmed loading across the perception of poor performance, whereas the o9 items loaded across the dimension of fear of negative evaluation. These 02 dimensions measure students' speech 
anxiety thoughts of speaking English (Cho et al., 2004). The items loadings of 22 items across 02 dimensions were above the suggested minimum loading value of 0.5 (Hair et al., 2014). These item loadings indicate that this measurement model is adequate and significant in male and female students (Figure 2 and 3; Table No. 3).

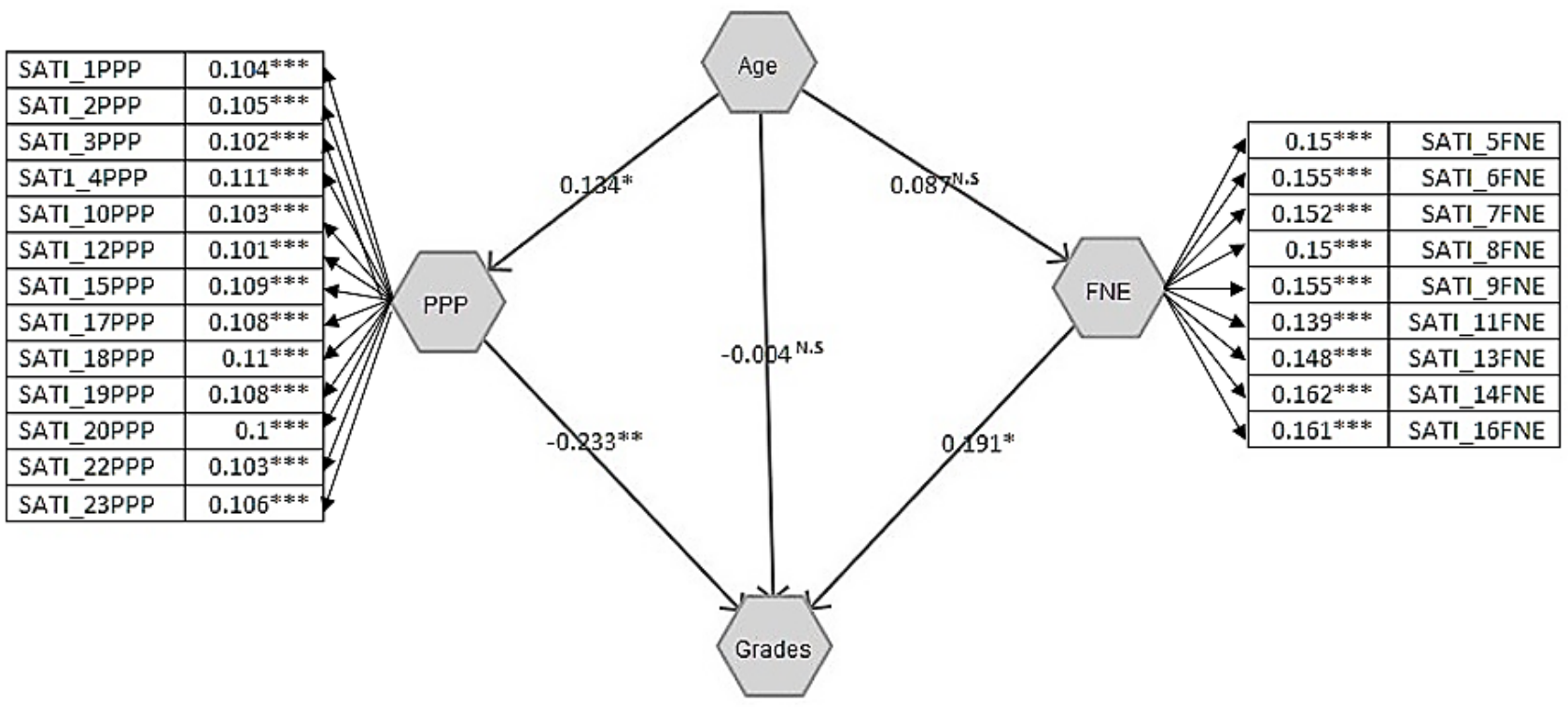

Figure 2: GSCA Model (Male Group)

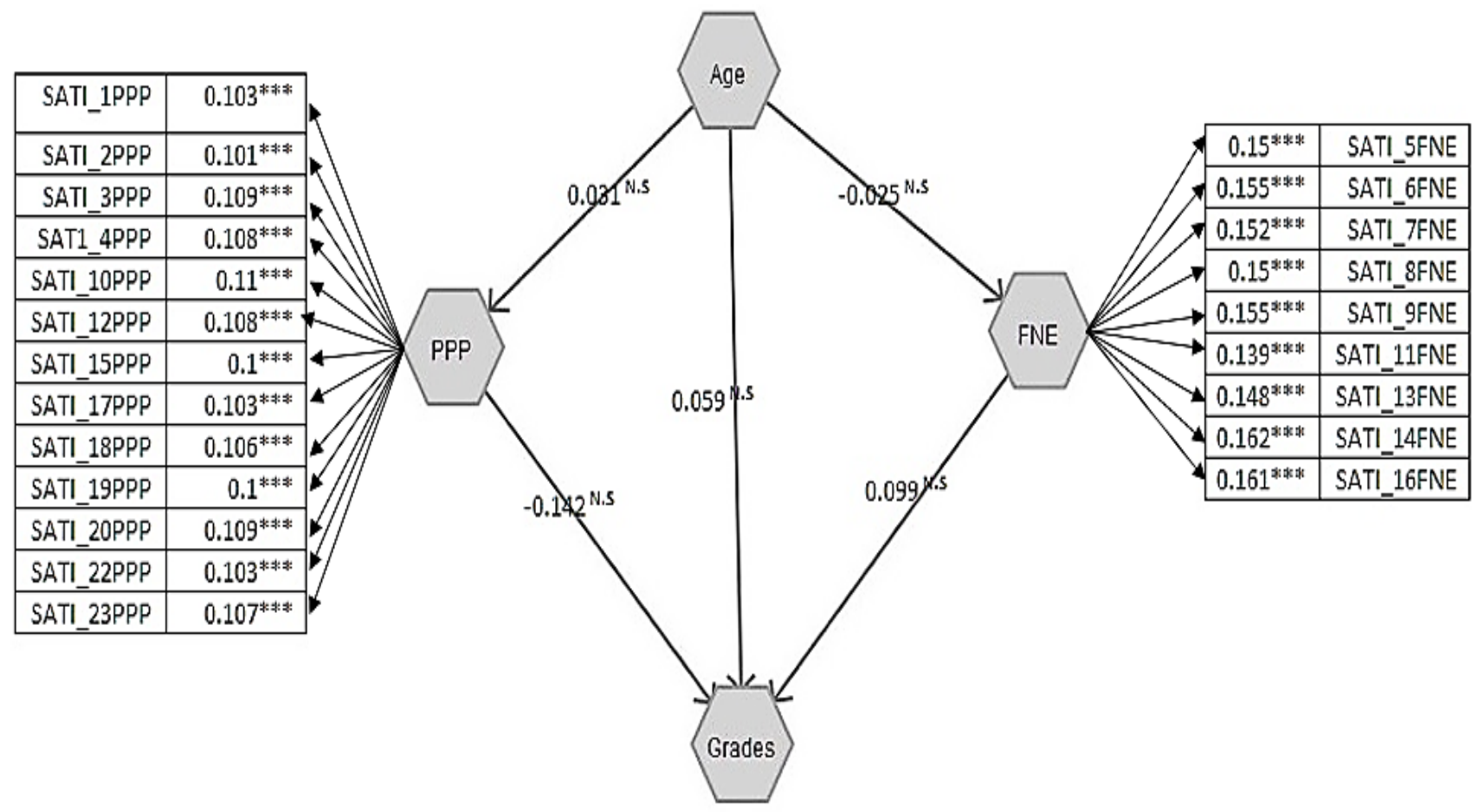

Figure 3: GSCA Model (Female Group) 
Review of Applied Management and Social Sciences (RAMSS) Vol. 4, (4) 2021, 863 - 880

\begin{tabular}{|c|c|c|c|c|c|c|c|}
\hline \multicolumn{8}{|l|}{$\begin{array}{l}\text { Table No. } 3 \\
\text { Item Loadings }\end{array}$} \\
\hline \multirow[t]{2}{*}{ Component } & \multirow{2}{*}{ Items } & \multirow{2}{*}{ Estimate } & \multirow{2}{*}{ SE } & \multicolumn{2}{|c|}{$95 \% \mathrm{CI}$} & \multirow[b]{2}{*}{ T-Statistics } & \multirow{2}{*}{$\begin{array}{l}\text { P- } \\
\text { Value }\end{array}$} \\
\hline & & & & LL & UL & & \\
\hline \multicolumn{8}{|l|}{ Male (Group) } \\
\hline \multirow[t]{13}{*}{$\begin{array}{l}\text { Perception of } \\
\text { Performance }\end{array}$} & SATI_1PPP & 0.104 & 0.003 & 0.098 & 0.111 & 34.67 & $\begin{array}{l}< \\
.0001 \\
\end{array}$ \\
\hline & SATI_2PPP & 0.105 & 0.005 & 0.096 & 0.114 & 21 & $\begin{array}{l}< \\
.0001 \\
\end{array}$ \\
\hline & SATI_3PPP & 0.102 & 0.005 & 0.093 & 0.111 & 20.4 & $\begin{array}{l}< \\
.0001\end{array}$ \\
\hline & SAT1_4PPP & 0.111 & 0.004 & 0.103 & 0.121 & 27.75 & $\begin{array}{l}< \\
.0001 \\
\end{array}$ \\
\hline & SATI_10PPP & 0.103 & 0.005 & 0.093 & 0.113 & 20.6 & $\begin{array}{l}< \\
.0001 \\
\end{array}$ \\
\hline & SATI_12PPP & 0.101 & 0.004 & 0.093 & 0.109 & 25.25 & $\begin{array}{l}< \\
.0001 \\
\end{array}$ \\
\hline & SATI_15PPP & 0.109 & 0.005 & 0.1 & 0.118 & 21.8 & $\begin{array}{l}< \\
.0001 \\
\end{array}$ \\
\hline & SATI_17PPP & 0.108 & 0.004 & 0.1 & 0.116 & 27 & $\begin{array}{l}< \\
.0001 \\
\end{array}$ \\
\hline & SATI_18PPP & 0.11 & 0.005 & 0.102 & 0.119 & 22 & $\begin{array}{l}< \\
.0001\end{array}$ \\
\hline & SATI_19PPP & 0.108 & 0.005 & 0.1 & 0.118 & 21.6 & $\begin{array}{l}< \\
.0001 \\
\end{array}$ \\
\hline & SATI_20PPP & 0.1 & 0.004 & 0.091 & 0.107 & 25 & $\begin{array}{l}< \\
.0001 \\
\end{array}$ \\
\hline & SATI_22PPP & 0.103 & 0.004 & 0.095 & 0.111 & 25.75 & $\begin{array}{l}< \\
.0001 \\
\end{array}$ \\
\hline & SATI_23PPP & 0.106 & 0.004 & 0.098 & 0.114 & 26.5 & $\begin{array}{l}< \\
.0001 \\
\end{array}$ \\
\hline \multirow[t]{8}{*}{$\begin{array}{l}\text { Fear of Negative } \\
\text { Evaluation }\end{array}$} & SATI_5FNE & 0.15 & 0.006 & 0.137 & 0.161 & 25 & $\begin{array}{l}< \\
.0001 \\
\end{array}$ \\
\hline & SATI_6FNE & 0.155 & 0.006 & 0.143 & 0.165 & 25.83 & $\begin{array}{l}< \\
.0001 \\
\end{array}$ \\
\hline & SATI_7FNE & 0.152 & 0.005 & 0.143 & 0.162 & 30.4 & $\begin{array}{l}< \\
.0001 \\
\end{array}$ \\
\hline & SATI_8FNE & 0.15 & 0.006 & 0.141 & 0.162 & 25 & $\begin{array}{l}< \\
.0001 \\
\end{array}$ \\
\hline & SATI_9FNE & 0.155 & 0.006 & 0.141 & 0.168 & 25.83 & $\begin{array}{l}< \\
.0001 \\
\end{array}$ \\
\hline & SATI_11FNE & 0.139 & 0.006 & 0.128 & 0.149 & 23.17 & $\begin{array}{l}< \\
.0001 \\
\end{array}$ \\
\hline & SATI_13FNE & 0.148 & 0.006 & 0.14 & 0.161 & 24.67 & $\begin{array}{l}< \\
.0001\end{array}$ \\
\hline & SATI_14FNE & 0.162 & 0.006 & 0.152 & 0.174 & 27 & $\begin{array}{l}< \\
.0001 \\
\end{array}$ \\
\hline
\end{tabular}


Review of Applied Management and Social Sciences (RAMSS) Vol. 4, (4) 2021, 863 - 880

\begin{tabular}{|c|c|c|c|c|c|c|c|}
\hline & SATI_16FNE & 0.161 & 0.006 & 0.151 & 0.173 & 26.83 & $\begin{array}{l}< \\
.0001 \\
\end{array}$ \\
\hline \multicolumn{8}{|l|}{ Female Group } \\
\hline \multirow[t]{13}{*}{$\begin{array}{lll}\begin{array}{l}\text { Perception } \\
\text { Performance }\end{array} & \text { of } & \\
\end{array}$} & SATI_1PPP & 0.103 & 0.005 & 0.093 & 0.113 & 20.6 & $\begin{array}{l}< \\
.0001 \\
\end{array}$ \\
\hline & SATI_2PPP & 0.101 & 0.004 & 0.093 & 0.109 & 25.25 & $\begin{array}{l}< \\
.0001\end{array}$ \\
\hline & SATI_3PPP & 0.109 & 0.005 & 0.1 & 0.118 & 21.8 & $\begin{array}{l}< \\
.0001 \\
\end{array}$ \\
\hline & SAT1_4PPP & 0.108 & 0.004 & 0.1 & 0.116 & 27 & $\begin{array}{l}< \\
.0001\end{array}$ \\
\hline & SATI_10PPP & 0.11 & 0.005 & 0.102 & 0.119 & 22 & $\begin{array}{l}< \\
.0001\end{array}$ \\
\hline & SATI_12PPP & 0.108 & 0.005 & 0.1 & 0.118 & 21.6 & $\begin{array}{l} \\
.0001 \\
\end{array}$ \\
\hline & SATI_15PPP & 0.1 & 0.004 & 0.091 & 0.107 & 25 & $\begin{array}{l}< \\
.0001\end{array}$ \\
\hline & SATI_17PPP & 0.103 & 0.004 & 0.095 & 0.111 & $25 \cdot 75$ & $\begin{array}{l} \\
.0001\end{array}$ \\
\hline & SATI_18PPP & 0.106 & 0.004 & 0.098 & 0.114 & 26.5 & $\begin{array}{l}< \\
.0001\end{array}$ \\
\hline & SATI_19PPP & 0.1 & 0.004 & 0.093 & 0.108 & 25 & $\begin{array}{l}< \\
.0001\end{array}$ \\
\hline & SATI_2OPPP & 0.109 & 0.004 & 0.099 & 0.119 & 27.25 & $\begin{array}{l}< \\
.0001\end{array}$ \\
\hline & SATI_22PPP & 0.103 & 0.004 & 0.096 & 0.112 & $25 \cdot 75$ & $\begin{array}{l}< \\
.0001\end{array}$ \\
\hline & SATI_23PPP & 0.107 & 0.004 & 0.099 & 0.114 & 26.75 & $\begin{array}{l}< \\
.0001\end{array}$ \\
\hline \multirow[t]{9}{*}{$\begin{array}{l}\text { Fear of Negative } \\
\text { Evaluation }\end{array}$} & SATI_5FNE & 0.15 & 0.006 & 0.137 & 0.161 & 25 & $\begin{array}{l}< \\
.0001\end{array}$ \\
\hline & SATI_6FNE & 0.155 & 0.006 & 0.143 & 0.165 & 25.83 & $\begin{array}{l}< \\
.0001 \\
\end{array}$ \\
\hline & SATI_7FNE & 0.152 & 0.005 & 0.143 & 0.162 & 30.4 & $\begin{array}{l}< \\
.0001\end{array}$ \\
\hline & SATI_8FNE & 0.15 & 0.006 & 0.141 & 0.162 & 25 & $\begin{array}{l}< \\
.0001 \\
\end{array}$ \\
\hline & SATI_9FNE & 0.155 & 0.006 & 0.141 & 0.168 & 25.83 & $\begin{array}{l}< \\
.0001\end{array}$ \\
\hline & SATI_11FNE & 0.139 & 0.006 & 0.128 & 0.149 & 23.17 & $\begin{array}{l}< \\
.0001 \\
\end{array}$ \\
\hline & SATI_13FNE & 0.148 & 0.006 & 0.14 & 0.161 & 24.67 & $\begin{array}{l}< \\
.0001\end{array}$ \\
\hline & SATI_14FNE & 0.162 & 0.006 & 0.152 & 0.174 & 27 & $\begin{array}{l} \\
.0001 \\
.000\end{array}$ \\
\hline & SATI_16FNE & 0.161 & 0.006 & 0.151 & 0.173 & 26.83 & $\begin{array}{l}< \\
.0001 \\
\end{array}$ \\
\hline
\end{tabular}


The component quality or construct quality measures are in Table No. 4. This Table shows that the proportion of variance explained (PVE) by fear of negative evaluation and perception of poor performance is above the value of 0.50 in male and female students. Likewise, the internal consistency measure Alpha and composite reliability measure Rho values are above o.70 (Table 4). The values in Table No. 4 indicate that these items and constructs have acceptable convergent validity, internal consistency, and composite reliability in the male and female sample (Hair et al., 2014).

\begin{tabular}{|c|c|c|c|c|}
\hline \multicolumn{5}{|c|}{ Table No.4 } \\
\hline \multicolumn{5}{|c|}{ Construct quality measures } \\
\hline \multirow{3}{*}{ Measure } & \multicolumn{2}{|l|}{ Male Group } & \multicolumn{2}{|l|}{ Female (Group) } \\
\hline & $\begin{array}{l}\text { Perception of } \\
\text { Poor } \\
\text { Performance }\end{array}$ & $\begin{array}{l}\text { Fear of } \\
\text { Negative } \\
\text { Evaluation }\end{array}$ & $\begin{array}{l}\text { Perception of } \\
\text { Poor } \\
\text { Performance }\end{array}$ & $\begin{array}{l}\text { Fear } \\
\text { Negative } \\
\text { Evaluation }\end{array}$ \\
\hline & \multicolumn{2}{|l|}{ Male Group } & \multicolumn{2}{|c|}{ Female (Group) } \\
\hline PVE & 0.534 & 0.531 & 0.547 & 0.56 \\
\hline Alpha & 0.927 & 0.89 & 0.931 & 0.902 \\
\hline Rho & 0.937 & 0.911 & 0.94 & 0.92 \\
\hline
\end{tabular}

The measurement model suitability is further elaborated by the Heterotrait-Monotrait ratio (HTMT) of the correlations. The HTMT ratio of both components, the perception of poor performance and fear of negative evaluation, is below 0.90 in both groups of gender (Table No. 5). The value of HTMT above 0.90 is considered a threat to discriminant validity (Henseler et al., 2015).

\begin{tabular}{|c|c|}
\hline \multicolumn{2}{|l|}{ Table No. 5} \\
\hline \multicolumn{2}{|c|}{ Heterotrait-Monotrait (HTMT) } \\
\hline Male (Group) & Female (Group) \\
\hline PPP $\leftrightarrow$ FNE & PPP $\leftrightarrow$ FNE \\
\hline 0.837 & 0.855 \\
\hline
\end{tabular}

$\mathrm{PPP}=$ Perception of Poor Performance, $\mathrm{FNE}=$ Fear of Negative Evaluation

Table Nos. 2, 3, 4, and 5 and Figures 2 and 3 show that the measurement model espoused by Cho et al. (2004) has adequate psychometric relevance across male and female students in Pakistan. Therefore, it can measure negative thoughts in speaking English in Pakistani university students.

\subsubsection{Structural Model}

The magnitude and significance of different path estimates in the model for male and female students are shown in Table 6 and Figures 2 and 3. The female gender does not significantly influence the relationships of female students' age on their perceptions of poor performance, fear of negative evaluation, and academic grades. In female respondents' group, the impacts of variable age on students' academic grades, perceptions of poor performance in English speaking, fear of negative evaluation in speaking English, and effects of fear of negative evaluation in speaking English and perception of poor performance on students' academic grades are not significant and considerable (Table 6, and Figure 2 and 3). On the other hand, there is a somewhat different pattern of interrelationships in the male group. Although the impacts of variable age on students 'academic 
grades and fear of negative evaluation in speaking English are insignificant, there are significant positive impacts of students' age on their perceptions of poor performance in the male group of students, and positive impacts of fear of negative evaluation on students' academic grades as compared to the significant negative effects of perceptions of poor performance in English speaking on their academic grades. There are different causes and factors for the development of fear of negative evaluation and perceptions of poor performance in speaking English in male and female students' that might have different implications for their academic performance.

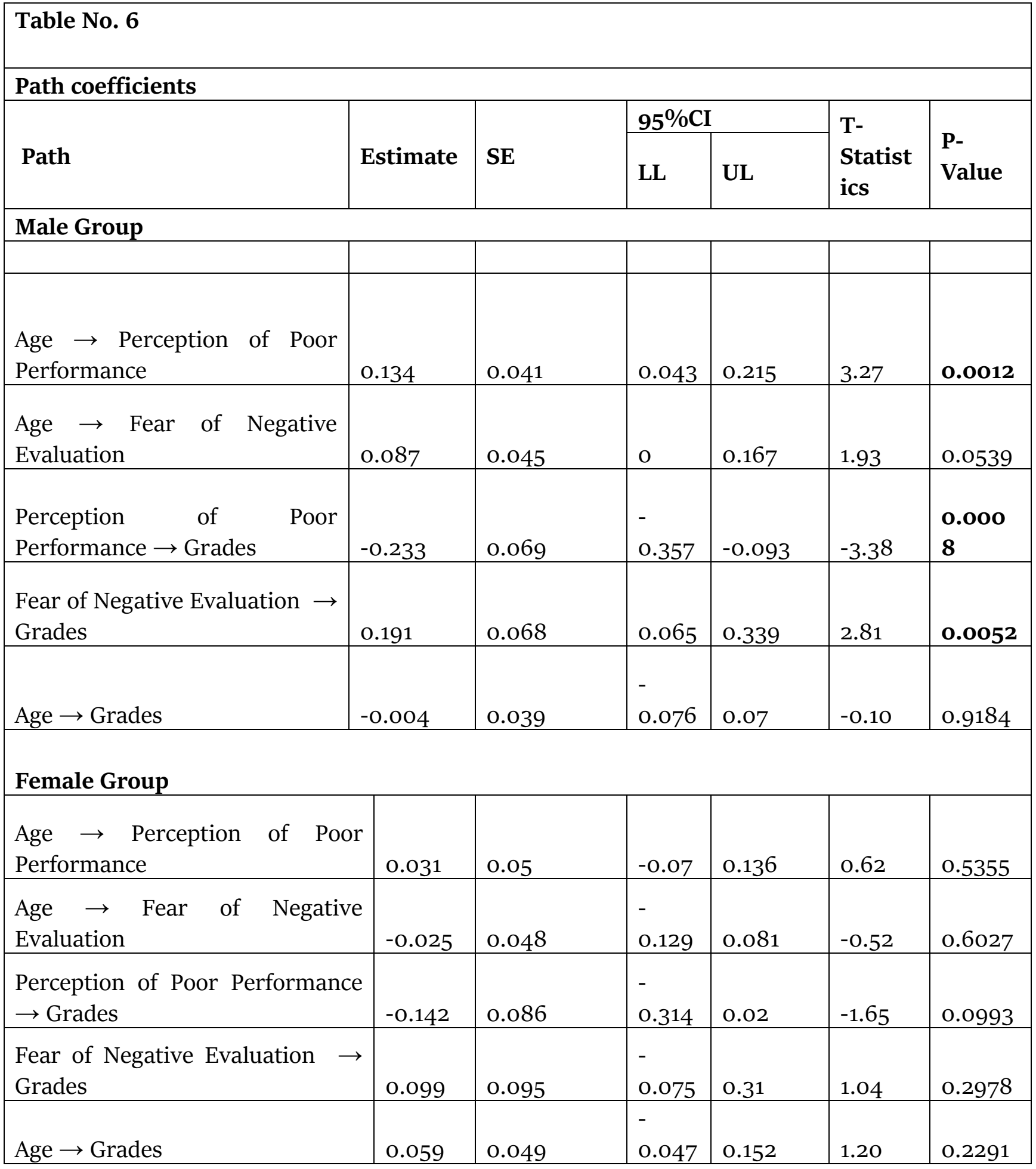


Table No. 7 shows were very small effect sizes in the female group compared to the male group. In female students' only the effect size of perception of poor performance on academic grades (0.02) falls in the category of small effect size. The remaining effect sizes in the model in female students fall even below the predefined level of small effects size of 0.02 (Hair et al., 2014). However, there was a small effect of perceptions of poor performance on students' academic grades (0.058), similar to a small effect size of fear of negative evaluation in academic grades (0.038) in male students.

\begin{tabular}{|c|c|c|c|c|c|}
\hline \multicolumn{5}{|c|}{ Table No. 7} & Effect Sizes \\
\hline & Latent Variable & $\begin{array}{l}\text { Perception of Poor } \\
\text { Performance }\end{array}$ & $\begin{array}{l}\text { Fear of Negative } \\
\text { Evaluation }\end{array}$ & $\begin{array}{l}\text { Academic } \\
\text { Grades }\end{array}$ & Age \\
\hline \multirow{4}{*}{$\begin{array}{l}\text { Male } \\
\text { Group }\end{array}$} & $\begin{array}{l}\text { Perception of Poor } \\
\text { Performance }\end{array}$ & & & 0.058 & \\
\hline & $\begin{array}{l}\text { Fear of Negative } \\
\text { Evaluation }\end{array}$ & & & 0.038 & \\
\hline & Academic Grades & & & & \\
\hline & Age & 0.018 & 0.008 & & \\
\hline \multirow{4}{*}{$\begin{array}{l}\text { Female } \\
\text { Group }\end{array}$} & $\begin{array}{l}\text { Perception of Poor } \\
\text { Performance }\end{array}$ & & & 0.02 & \\
\hline & $\begin{array}{l}\text { Fear of Negative } \\
\text { Evaluation }\end{array}$ & & & 0.01 & \\
\hline & Academic Grades & & & & \\
\hline & Age & 0.001 & 0.001 & 0.004 & \\
\hline
\end{tabular}

The mediation analysis revealed significant differences in the mediation role of dimensions of English speech anxiety. The perceptions of poor performance and fear of negative evaluation did not mediate the impacts of students' age on their academic grades in the female group of students (Table No. 8). However, there was full mediation by students' perceptions of poor performance in speaking English in determining the impact of their age on their academic grades in male students (Table No. 8). Though the male students' fear of negative evaluation in speaking English was positively associated with their academic grades, their fear of negative evaluation in speaking English did not mediate the impact of students' age on their academic grades. 
Review of Applied Management and Social Sciences (RAMSS) Vol. 4, (4) 2021, $863-880$

\begin{tabular}{|c|c|c|c|c|c|c|}
\hline \multicolumn{7}{|l|}{ Table No. 8} \\
\hline \multicolumn{7}{|c|}{ Summary of Mediation Results } \\
\hline \multirow[t]{3}{*}{ Hypothesis } & \multirow{3}{*}{$\begin{array}{l}\text { Direct } \\
\text { Effect } \\
A C C \\
\end{array}$} & \multicolumn{2}{|c|}{ Indirect Effect } & \multirow{3}{*}{$\begin{array}{l}\text { Total } \\
\text { Indirect } \\
\text { Effects } \\
\mathrm{A} \rightarrow \mathrm{B} \rightarrow \mathrm{C}\end{array}$} & \multirow{3}{*}{$\begin{array}{l}\text { Total } \\
\text { Effects }\end{array}$} & \multirow[t]{3}{*}{ Mediation } \\
\hline & & & & & & \\
\hline & & $\mathbf{A} \rightarrow \mathbf{B}$ & $\mathrm{B} \rightarrow \mathrm{C}$ & & & \\
\hline \multicolumn{7}{|l|}{ Male Group } \\
\hline $\begin{array}{l}\text { Mediation by PPP in the } \\
\text { impact of age on } \\
\text { students' } \\
\text { performance }\end{array}$ & $\mathrm{O}_{\mathrm{S}}^{-}$ & $0.134^{*}$ & $-0.233^{*}$ & $-0.031^{*}$ & -0.035 & Full \\
\hline $\begin{array}{l}\text { Mediation by FNE in the } \\
\text { impact of age on } \\
\text { students' } \\
\text { performance }\end{array}$ & $\mathrm{O}_{\mathrm{S}}^{-}$ & $0.087^{\text {N.S }}$ & $0.191^{*}$ & $0.017^{\text {N.S }}$ & 0.013 & No \\
\hline \multicolumn{7}{|l|}{ Female Group } \\
\hline $\begin{array}{l}\text { Mediation by PPP in the } \\
\text { impact of age on } \\
\text { students } \\
\text { performance }\end{array}$ & $\begin{array}{l}\text { O.059 } \\
\text { N.S }\end{array}$ & $0.031^{\text {N.S }}$ & $-0.142^{N . S}$ & -0.004 & 0.055 & No \\
\hline $\begin{array}{l}\text { Mediation by FNE in the } \\
\text { impact of age on } \\
\text { students' } \\
\text { performance }\end{array}$ & $\begin{array}{l}\text { O.O59 } \\
\text { N.S }\end{array}$ & $-0.025^{N . S}$ & $0.099^{\text {N.S }}$ & -0.003 & 0.056 & No \\
\hline \multicolumn{7}{|c|}{$\begin{array}{l}\bullet=\text { significant, }{ }^{\text {N.S }}=\text { Non Significant, PPP }=\text { Perception of Poor Performance, FNE }=\text { Fear } \\
\text { of Negative Evaluation }\end{array}$} \\
\hline
\end{tabular}

\section{Discussion}

The results of this study affirm the preliminary study of Cho et al. (2004). They developed a scale to measure the cognitive aspects of English speech anxiety in students. Their study (Cho et al., 2004) revealed a two-factor structure of negative thoughts of students' English speaking anxiety. Our study affirmed their explored factor structure by using the confirmatory factor approach. Hence, this study adds evidence in favour of the two-factor structure of negative thoughts of English speech anxiety, and it warrants its use to measure students' cognitive aspects of English speaking anxiety in male and female students in Pakistan.

The literature indicates gender differences in students' academic performance (SparksWallace, 2007) and speaking anxiety (Dweck et al., 1978). Therefore, the results of this study strengthen the argument that gender differences exist in students' academic performance because of the diverse underlying cognitive attributes of information processing, learning approaches, epistemological beliefs, and regulation of learning in male and female students (Chiou et al., 2011; Lodewyk, 2007; Weis et al., 2013).

The students' age is a variable that impacts most of the students' characteristics related to academic performance (Toni et al., 2016; Voyles, 2011) and academic behaviour (Hofer \& Pintrich, 1997; Lake \& Boyd). However, this study found no direct impact of female and male students' age on their academic performance. However, there was a significant indirect impact of age on students' 
academic performance. The effect of age on students' academic performance was fully mediated by their perceptions of poor performance in English speech. This study reports a significant positive impact of age on students' perceptions of poor performance in English speaking anxiety and a negative impact of perceptions of poor performance on students' academic performance. This finding supports the conclusive literature about the relative effect of age on students' academic performance (Navarro et al., 2015). As students grow, changes in students' cognitive and affective attributes impact their academic behaviour and academic performance (Navarro et al., 2015; Xiao, 2018). The lack of direct impact of age on academic performance in this study may be because there is low variance in sampled students' age, and consequently, age has no significant direct impact or association with students' academic performance.

This study affirmed the significant impact of students' negative thoughts in speech anxiety on their academic performance (Aida, 1994). However, this impact was noticeable only in male students. Contrary to the overall negative effect of speech anxiety on academic performance, this study highlighted the significant specific impact of perceptions of poor performance and fear of negative evaluation in students' academic performance. The perceptions of poor performance are negatively associated with students' academic performance compared to the significant positive association of students' fear of negative evaluation with their academic performance. The literature has highlighted the negative impact of perceptions of poor performance on academic performance (Bruce, 2003) because it is associated with ability beliefs (Bernstein, 2006). The adverse effects of poor self-esteem or perceptions of poor ability hurdle students' effort to study, and due to negative ability and performance beliefs, the students even do not try to learn (Meltzer et al., 2004). It indicates their negative mindset or entity belief which is associated negatively with academic performance (Dweck, 2006). Students' negative perceptions of performance and ability make them believe that they cannot learn (Wilson, 2015).

On the other hand, the fear of negative evaluation depends on the students' interpretations. If students have a positive mindset, they can overcome criticism and improve academic performance. So if students have a negative attitude, then this fear of negative evaluation can have severe negative implications for students' academic behaviour (Fong et al., 2019).

The lack of significant impact of negative thoughts in speech anxiety on academic performance in female students indicates that there are different underlying dynamics of development of negative views of speech anxiety in female students than male students. Furthermore, the level of negative English speech thoughts in female students was not as high as in the male students. Consequently, there is no significant impact of negative thoughts in English speaking on female students' academic performance.

\section{Conclusion}

There are different factors responsible for developing negative thoughts of English speaking in male and female students. Implicit theories guide us about the personal and individualised dynamics of perceptions of poor performance and negative thoughts in male and female students. The different dimensions of English speech anxiety stimulate different impacts on students' academic behaviour and academic performance. For example, the perceptions of poor performance are closely associated with self-perception of ability and self-competence; therefore, perceptions of poor performance have a more adverse effect on students' academic performance. The poor perceptions of performance are signs of negative mindset or entity beliefs of intelligence. At the same 
time, the fear of negative evaluation can positively and negatively impact students' academic performance. If students have a negative mindset, it is negatively associated with academic performance. However, if students have a positive mindset and believe that ability and intelligence can change through training and education, then negative evaluation motivates students to put effort and perform better.

\section{Recommendations}

There is a need to evaluate students' implicit beliefs of intelligence, ability, and effort. The students who have a negative mindset should be provided interventions to change their mindset. Teachers should identify their students' attitudes, perceptions of poor performance, and fear of negative evaluation to counsel students.

\section{Policy Implications}

The negative mindset can handicap students' learning. The parents and teachers should have been trained to identify students' perspectives to guide students. The school environment should be supportive of students. The educational experts should train teachers to provide appropriate feedback to students. Teachers should know to avoid ability-based negative feedback because abilityrelated negative feedback can develop a negative mindset in students.

\section{References}

Aida, Y. (1994). Examination of Horwitz, Horwitz, and Cope's Construct of Foreign Language Anxiety: The Case of Students of Japanese. The Modern Language Journal, 78(2), 155-168. doi:10.2307/329005

Aydin, S., Harputlu, L., Çelik, Ş. S., Uştuk, Ö., \& Güzel, S. (2017). Age, gender and grade effect on foreign language anxiety among children. TEFLIN Journal, 28(2), 133-154. Retrieved from https://pdfs.semanticscholar.org/acfe/5cc29b3c232bd87eb7ac8e04c53a1ccb4d5e.pdf

Bandura, A. (1982). Self-efficacy mechanism in human agency. American Psychologist, 37(2), 122147. doi:10.1037/0003-066X.37.2.122

Bernstein, D. (2006). The impact of implicit theories of intelligence on the motivation of students with learning challenges. (3210259 Ph.D.), Fordham University, Ann Arbor. Retrieved from https://www.proquest.com/dissertations-theses/impact-implicit-theories-intelligenceon/docview/305332749/se-2 ?accountid=135034 ProQuest Dissertations \& Theses Global database.

Bledsoe, T. S., \& Baskin, J. J. (2014). Recognizing Student Fear: The Elephant in the Classroom. College Teaching, 62(1), 32-41. Retrieved from http://www.jstor.org/stable/24760535

Bruce, L. J. (2003). A comparison of teachers' perceptions and students' self-perceptions of reading ability at the grade four, five and six level. (MQ84210 M.A.), University of Toronto (Canada), Ann Arbor. Retrieved from https://www.proquest.com/dissertations-theses/comparisonteachers-perceptions-students-self/docview/305260066/se-2?accountid=135034 ProQuest Dissertations \& Theses Global database.

Carleton, R. N., McCreary, D. R., Norton, P. J., \& Asmundson, G. J. G. (2006). Brief Fear of Negative Evaluation scale-revised. Depression and Anxiety, 23(5), 297-303. doi:https://doi.org/10.1002/da.20142

Carr, P. B., Rattan, A., \& Dweck, C. S. (2012). Chapter three - Implicit Theories Shape Intergroup Relations. In P. Devine \& A. Plant (Eds.), Advances in Experimental Social Psychology (Vol. 45, pp. 127-165): Academic Press.

Chapman, J. W. (1988). Cognitive-motivational characteristics and academic achievement o f 
Review of Applied Management and Social Sciences (RAMSS) Vol. 4, (4) 2021, 863 - 880

learning disabled children: a longitudinal study. Journal of Educational Psychology, 8o(3), 357-336. doi:DOI:10.1037/0022-0663.80.3.357

Chiou, G.-L., Liang, J.-C., \& Tsai, C.-C. (2011). Undergraduate Students' Conceptions of and Approaches to Learning in Biology: A study of their structural models and gender differences. International Journal of Science Education, 34(2), 167-195. doi:10.1080/09500693.2011.558131

Cho, G., \& Choi, J. Y. (2020). An empirical comparison of generalized structured component analysis and partial least squares path modeling under variance-based structural equation models. Behaviormetrika, 47(1), 243-272. doi:10.1007/s41237-019-0oog8-o

Cho, Y., Smits, J. A. J., \& Telch, M. J. (2004). The Speech Anxiety Thoughts Inventory: scale development and preliminary psychometric data. Behaviour Research and Therapy, 42(2004), 13-25. doi:10.1016/Sooo5-7967(03)ooo67-6

Clark, D. M. (2001). A Cognitive Perspective on Social Phobia. In W. R. Crozier \& L. E. Alden (Eds.), International Handbook of Social Anxiety: Concepts, Research and Interventions Relating to the Self and Shyness: John Wiley \& Sons Ltd.

D'Esposito, S. E., Blake, J., \& Riccio, C. A. (2011). Adolescents' Vulnerability to Peer Victimization: Interpersonal and Intrapersonal Predictors. Professional School Counseling, 14(5), 299-309. Retrieved from http://www.jstor.org/stable/23801080

Das, S. K. (2019). Confidence interval is more informative than p-value in research. International Journal of Engineering Applied Sciences and Technology, 4(6), 278-282. Retrieved from http://www.ijeast.com)

Downing, V. R., Cooper, K. M., Cala, J. M., Gin, L. E., \& Brownell, S. E. (2020). Fear of Negative Evaluation and Student Anxiety in Community College Active-Learning Science Courses. CBE Life Sci Educ, 19(2), ar20. doi:10.1187/cbe.19-09-0186

Duco, J. (2016). Tracking and Student Perceptions: Theories of Intelligence and Effort Belief. (10152943 Ed.D.), Aurora University, Ann Arbor. Retrieved from https://www.proquest.com/dissertations-theses/tracking-student-perceptionstheories/docview/1835837135/se-2 ?accountid=135034 ProQuest Dissertations \& Theses Global database.

Dweck, C. S. (2000). Is Intelligence Fixed or Changeable? Students' Theories About Their Intelligence Foster Their Achievement Goals (C. S. D. C. University \& E. I. S. Psychology, Trans.) SelfTheories: Their Role in Motivation, Personality, and Development (pp. 36-). New York, Psychology Press: Taylor \& Francis Group.

Dweck, C. S. (2006). The truth about ability and accomplishment Mindset: The new psychology of success. Random House: New York.

Dweck, C. S., Chiu, C.-y., \& Hong, Y.-y. (1995). Implicit Theories and Their Role in Judgments and Reactions: A World from Two Perspectives. Psychological Inquiry, 6(4), 267-285. Retrieved from http://www.jstor.org/stable/1448940

Dweck, C. S., Davidson, W., Nelson, S., \& Enna, B. (1978). Sex differences in learned helplessness: II. The contingencies of evaluative feedback in the classroom and III. An experimental analysis. Developmental Psychology, 14(3), 268-276. doi:10.1037/0012-1649.14.3.268

Fong, C. J., Patall, E. A., Vasquez, A. C., \& Stautberg, S. (2019). A Meta-Analysis of Negative Feedback on Intrinsic Motivation. Educational Psychology Review, 31(1), 121-162. doi:10.1007/s10648018-9446-6

Gaibani, A., \& Elmenfi, F. (2016). Age as an Affective Factor in Influencing Public Speaking Anxiety of English Language Learners at Omar Al-Mukhtar Universit. Advances in Language and Literary Studies, 7(2), 179-182. Retrieved from https://files.eric.ed.gov/fulltext/EJ1127085.pdf 
Gardner, R. C., \& MacIntyre, P. D. (1993). On the Measurement of Affective Variables in Second Language Learning. Language Learning, 43(2), 157-194. doi:https://doi.org/10.1111/j.14671770.1992.tboo714.X

Hair, J., F., Hult, G., Tomas, M., Ringle, C., M., \& Sarstedt, M. (2014). Primer on Partial Least Squares Structural Equation Modeling (PLS-SEM). California, USA: SAGE Publications, Inc.

Henseler, J., Ringle, C. M., \& Sarstedt, M. (2015). A new criterion for assessing discriminant validity in variance-based structural equation modeling. Journal of the Academy of Marketing Science, 43(1), 115-135 . doi:https://doi.org/10.1007/s11747-014-0403-8

Hofer, B. K., \& Pintrich, P. R. (1997). The Development of Epistemological Theories: Beliefs About Knowledge and Knowing and Their Relation to Learning. Review of Educational Research, 67(1), 88-140. doi:10.3102/00346543067001088

Hwang, H. (2009). Regularized Generalized Structured Component Analysis. Psychometrika, 74(3), 517-530. doi:10.1007/s11336-0o9-9119-y

Hwang, H., \& Takane, Y. (2014). Generalized Structured Component Analysis: A Component-Based Approach to Structural Equation Modeling: Chapman and Hall/CRC.

Hwang, H., Takane, Y., \& Jung, K. (2017). Generalized Structured Component Analysis with Uniqueness Terms for Accommodating Measurement Error. Frontiers in psychology, 8(2137). doi:10.3389/fpsyg.2017.02137

Kitano, K. (2001). Anxiety in the College Japanese Language Classroom. The Modern Language Journal, 85(4), 549-566. Retrieved from http://www.jstor.org/stable/1193075

Lake, W., \& Boyd, W. Age, Maturity and Gender, and the Propensity towards Surface and Deep Learning Approaches amongst University Students. Creative Education, 6, 2361-2371. Retrieved from https://www.researchgate.net/publication/288059391_Age_Maturity _and_Gender_and_the_Propensity_towards_Surface_and_Deep_Learning_Approaches_amon gst_University_Students/link/567fdocoo8aeo51f9ae7a6af/download

Liu, M., \& Jackson, J. (2008). An Exploration of Chinese EFL Learners' Unwillingness to Communicate and Foreign Language Anxiety. The Modern Language Journal, 92(1), 71-86. Retrieved from http://www.jstor.org/stable/25172993

Lodewyk, K. R. (2007). Relations among Epistemological Beliefs, Academic Achievement, and Task Performance in Secondary School Students. Educational Psychology, 27(3), 307-327. doi:10.1080/01443410601104080

Lüftenegger, M., \& Chen, J. A. (2017). Conceptual Issues and Assessment of Implicit Theories. Retrieved from https://scholarworks.wm.edu/cgi/viewcontent.cgi?article $=1158 \&$ context =educationpubs

Meltzer, L., Reddy, R., Pollica, L. S., Roditi, B., Sayer, J., \& Theokas, C. (2004). Positive and Negative Self-Perceptions: Is There a Cyclical Relationship Between Teachers' and Students' Perceptions of Effort, Strategy Use, and Academic Performance? Learning Disabilities Research \& Practice, 19(1), 33-44. doi:https://doi.org/10.1111/j.1540-5826.2004.00087.X

Navarro, J.-J., García-Rubio, J., \& Olivares, P. R. (2015). The Relative Age Effect and Its Influence on Academic Performance. PLoS ONE, 10(10), doi:10.1371/journal.pone.0141895

Nunan, D. (2003). The Impact of English as a Global Language on Educational Policies and Practices in the Asia-Pacific Region. TESOL Quarterly, 37(4), 589-613. doi:10.2307/3588214

Pappamihiel, N. E. (2002). English as a Second Language Students and English Language Anxiety: Issues in the Mainstream Classroom. Research in the Teaching of English, 36(3), 327-355. Retrieved from http://www.jstor.org/stable/40171530

Plaks, J. E. (2017). Chapter Five - Implicit Theories: Assumptions That Shape Social and Moral Cognition. In J. M. Olson (Ed.), Advances in Experimental Social Psychology (Vol. 56, pp. 259- 
310): Academic Press.

Seipp, B. (1991). Anxiety and academic performance: A meta-analysis of findings. Anxiety Research, 4(1), 27-41. doi:10.1080/o8917779108248762

Sparks-Wallace, O. J. (2007). A Study of Gender Differences in Academic Performance in a Rural County in Tennessee. (Master of Arts in Sociology), East Tennessee State University Johnson City, Tennessee. Retrieved from https://dc.etsu.edu/cgi/viewcontent.cgi?article=3462 \&context $=$ etd

Stewart, C. O., McConnell, J. R., Stallings, L. A., \& Roscoe, R. D. (2019). Growth Mindset: Associations with Apprehension, Self-Perceived Competence, and Beliefs about Public Speaking. Basic Communication Course Annual, 31(6). Retrieved from https://ecommons.udayton.edu/bcca/ vol31/iss1/6

Thompson, E. H., Robertson, P., Curtis, R., \& Frick, M. H. (2013). Students with Anxiety: Implications for Professional School Counselors. Professional School Counseling, 16(4), 222-234. Retrieved from http://www.jstor.org/stable/profschocoun.16.4.222

Toni, M., Mardesic, J., \& Kovac, G. (2016, 2016-06-16 - 2016-o6-18). Do gender and age impact student success? Paper presented at the Contemporary issues in economy \& technology (CIET2016), Split, Croatia.

Voyles, M. J. (2011). Student academic success as related to student age and gender. (Doctor of Education Degree), University of Tennessee Chattanooga, Tennessee. Retrieved from https://scholar.utc.edu/cgi/viewcontent.cgi?article=1085\&context=theses

Weis, M., Heikamp, T., \& Trommsdorff, G. (2013). Gender differences in school achievement: The role of self-regulation. Frontiers in psychology, 4, 442. Retrieved from https://www. frontiersin.org/article/10.3389/fpsyg.2013.00442

Wilson, C. L. (2015). The effect of implicit self-theories of intelligence on task persistence and performance in an adult sample: Test of a structural model. (3720904 Ph.D.), Colorado State University, Ann Arbor. Retrieved from https://www.proquest.com/dissertationstheses/effect-implicit-self-theories-intelligence-on/docview/1717099513/se2?accountid=135034 ProQuest Dissertations \& Theses Global database.

Xiao, D. (2018). Relative Age Effect in High School Academic Performance. Weinberg College of Arts \& Sciences, Evanston,. Retrieved from https://mmss.wcas.northwestern.edu/thesis/articles/ get/993/xiaodi_17663_5396082_Senior\%20Thesis\%20.pdf

Young, D. J. (1991). Creating a Low-Anxiety Classroom Environment: What Does Language Anxiety Research Suggest? The Modern Language Journal, 75(4), 426-439. doi:10.2307/329492

Zhang, N., \& Henderson, C. N. R. (2014). Test anxiety and academic performance in chiropractic students. The Journal of chiropractic education, 28(1), 2-8. doi:10.7899/JCE-13-20 